\title{
Statement on Matching Language to the Type of Evidence Used in Describing Outcomes Data
}

\author{
Editors of the HEART Group Journals
}

There are many different types of studies that can be conducted to provide evidence for clinical and outcomes research, including but not limited to retrospective observational analyses, case-control studies, and randomized controlled trials (RCTs). Each of these analyses has strengths and limitations, but most importantly, they all result in different types of conclusions about an intervention.

As illustrated in a series of examples provided in a separate review, ${ }^{1}$ inappropriate word choice to describe results can lead to scientific inaccuracy. Therefore, the editors of the HEART Group (representing the world's cardiovascular journals) recommend that all investigators and editors carefully select language to "match" the type of study conducted, without overstating findings or drawing erroneous conclusions about causality when they cannot be established.

As an illustrative example, when reporting results from an observational study that shows fewer deaths in one arm than in another, one should use descriptive statements such as, "the intervention is associated with lower mortality," rather than definitive statements such as, "the intervention reduces mortality." Conversely, when reporting the results of a rigorously conducted RCT with complete follow-up, in which the only difference captured between the 2 groups was the intervention, it may be appropriate to use somewhat more declarative statements such as, "the intervention reduced risk." Additional examples of language matched with corresponding study type are listed in the Table 1.

In conclusion, all manuscripts should be written and edited not only for scientific accuracy but also
Table 1. Suggested Language Based on Study Type.

\begin{tabular}{|c|c|c|}
\hline & $\begin{array}{l}\text { Randomized } \\
\text { Trial }\end{array}$ & $\begin{array}{c}\text { Observational } \\
\text { Study }\end{array}$ \\
\hline \multicolumn{3}{|l|}{ Type of language } \\
\hline $\begin{array}{l}\text { Descriptive } \\
\text { statements }\end{array}$ & $\begin{array}{l}\text { "Reduced the } \\
\text { risk by" }\end{array}$ & $\begin{array}{l}\text { "A lower risk } \\
\text { was } \\
\text { observed," } \\
\text { "there is a } \\
\text { relationship," } \\
\text { "there is an } \\
\text { association" }\end{array}$ \\
\hline $\begin{array}{l}\text { Descriptive } \\
\text { nouns }\end{array}$ & $\begin{array}{l}\text { "Relative risk } \\
\text { reduc- } \\
\text { tions"benefit" }\end{array}$ & $\begin{array}{l}\text { "Difference in } \\
\text { risk," "risk } \\
\text { ratio" }\end{array}$ \\
\hline \multirow[t]{2}{*}{ Verbs } & $\begin{array}{l}\text { "Affected," } \\
\text { "caused," }\end{array}$ & $\begin{array}{l}\text { "Correlates } \\
\text { with," "is } \\
\text { associated } \\
\text { with" }\end{array}$ \\
\hline & $\begin{array}{l}\text { “modulated } \\
\text { risk," } \\
\text { "treatment } \\
\text { resulted in," } \\
\text { "reduced } \\
\text { hazard" }\end{array}$ & \\
\hline $\begin{array}{l}\text { Incorrect } \\
\text { terms/avoid } \\
\text { using }\end{array}$ & & $\begin{array}{c}\text { "Reduced risk" } \\
\text { (active verb), } \\
\text { "lowered risk" } \\
\text { (active verb), } \\
\text { "benefitted" }\end{array}$ \\
\hline
\end{tabular}

With permission from Kohli and Cannon. ${ }^{1}$

for appropriateness of language used in describing the level of evidence provided by the study.

\section{REFERENCE}

1. Kohli $\mathrm{P}$, Cannon CP. The importance of matching language to type of evidence: avoiding the pitfalls of reporting outcomes data. Clin Cardiol 2012;35:714-717 